\title{
Moisture Sources and Life Cycle of Convective Systems over Western Colombia
}

\author{
Meiry Sayuri Sakamoto, ${ }^{1}$ Tércio Ambrizzi, ${ }^{2}$ and Germán Poveda ${ }^{3}$ \\ ${ }^{1}$ Research Institute for Meteorology and Water Resources, Avenida Rui Barbosa, 1246, 60115-221 Fortaleza, CE, Brazil \\ ${ }^{2}$ Institute of Astronomy, Geophysics and Atmospheric Sciences, University of São Paulo, São Paulo, SP, Brazil \\ ${ }^{3}$ Escuela de Geociencias y Medio Ambiente, Universidad Nacional de Colombia, Sede Medellín, Medellín, Colombia \\ Correspondence should be addressed to Meiry Sayuri Sakamoto, meiry@funceme.br
}

Received 31 August 2011; Revised 7 December 2011; Accepted 8 December 2011

Academic Editor: Klaus Dethloff

Copyright (๑) 2011 Meiry Sayuri Sakamoto et al. This is an open access article distributed under the Creative Commons Attribution License, which permits unrestricted use, distribution, and reproduction in any medium, provided the original work is properly cited.

This paper describes life cycle and moisture sources of mesoscale convective systems (MCSs) observed over western Colombia. Results show that, in general, MCS are more frequent during boreal summer and autumn, and particularly, systems observed in summer season present longer life and larger extension. On the continent, MCS genesis is strongly affected by sea breeze and diurnal heating and presents a peak from 15 to 18 LST. For oceanic systems, the main genesis period is later, from 00 to 03 LST. Continental and oceanic systems present a tendency of westward displacement. Analysis using a Lagrangian approach implemented to estimate air parcel trajectories suggests that, during boreal winter, the main moisture sources are from the Caribbean Sea and tropical north Atlantic, possibly resulting from the moisture-laden trade winds and the land-ocean temperature contrast over northern South America. In summer, it is clear the influence of ITCZ positioning with moisture particles traveling from the tropical Atlantic over Amazonian river basin. In Autumn, Chilean-Peruvian Pacific is the main moisture source, confirming the importance of Chocó low level jet to MCS genesis.

\section{Introduction}

The western portion of Colombia is considered one of the rainiest on earth [1-3], with an annual average precipitation ranging from 8,000 to $13,000 \mathrm{~mm}$ [4]. In general, the rainfall follows the declination of the Sun, and a maximum is observed during the June-August period [3]. This rain is mostly of convective type [5-8], and as shown by Velasco and Fritsch [9] and Machado et al. [10], a large number of mesoscale convective systems (MCSs) develop over western Colombia both inland and off the Pacific coast. The MCSs contribute to $70 \%$ of annual precipitation, as shown by the data from the Tropical Rainfall Measuring Mission (TRMM) during the 1998-2002 period [11].

Systems observed over the Pacific coast of Colombia are strongly influenced by local topography $[9,12,13]$. The coast presents a north-south-oriented concave shape and inland, the Andes Mountains branch out at their northern tip forming long and deep intra-Andean south-north valleys (Figure 1). Such a complex topography combined with sea surface temperature variability off the Pacific coast gives rise to conditions leading to the development of MCSs $[3,9]$. Poveda and Mesa [4] suggested that the development of deep convection in this area results from moisture convergence by a westerly low-level jet named Chocó Jet, combined with high-level easterly trade winds, orographic lifting on the western Andes, low surface pressures and warm air. Based on satellite images and numerical model results, Mapes et al. [3] have observed a diurnal shift across the coastline, with an afternoon and evening rain prevailing over land, and severe late night and morning rain beginning inland and later on moving offshore. The results of Mapes et al. [14] indicated that these near-coastal afternoon/evening convection over land could be a response of the high Andes to solar heating, turbulent transfer of heat and moisture to the boundary layer, and the effect of sea-breeze front lifting the air. However, in case of the diurnal cycle observed in oceanic rainfall, their results indicated the propagation of a diurnal gravity wave as the mechanism to drive convection offshore, and not the analogous counterpart land-breeze. Velasco 


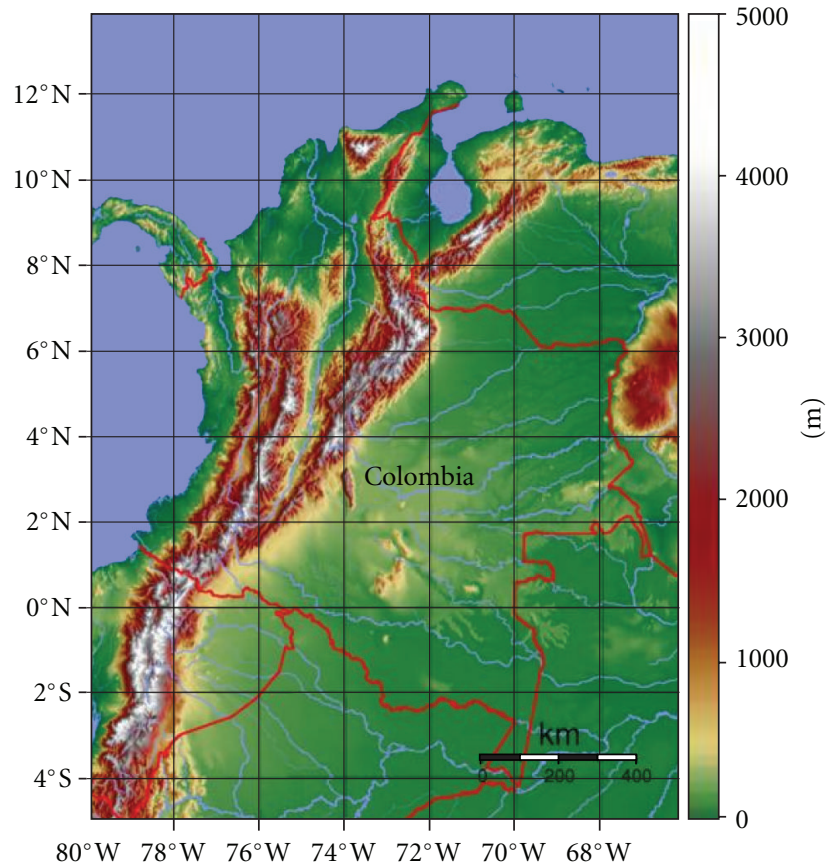

Figure 1: Topographic characteristics of Colombia. Terrain elevations are color banded in 1,000 meters intervals. Adapted from http://en.wikipedia.org/wiki/File:Colombia_Topography.png.

and Fritsch [9] observed that mesoscale convective complexes (MCCs) generated during southern hemisphere warm season (November to April) are distinctly nocturnal and are initiated at late night, with no major differences between continental or oceanic systems. Machado et al. [10], also based on satellite images, made a tracking of MCSs during their life cycle and observed that western Colombian systems propagation throughout the year presented a zonal alignment, mainly from east to west, except in boreal winter, when they showed more varied directions.

Even though some foremost aspects of these convective systems and local rainfall characteristics have been identified, there are still important convective systems features that need to be investigated in the western Colombia, related, for instance, to the moisture sources origin and their variability during the year. Previous studies, which used satellite images to detect convection, such as Velasco and Fritsch [9], Garreaud and Wallace [7], and Machado et al. [10] analyzed systems observed in all South America, although not specifically in western Colombia. The seminal paper of Velasco and Fritsch [9] explored the diurnal variation during two austral summer seasons. Garreaud and Wallace [7] analyzed nine years of satellite images, although they did not discuss the diurnal cycle of convection. Among the few studies focused on the region, there are those from Mapes et al. $[3,14]$ and Warner et al. [15], both of which used 3-hour infrared brightness temperature dataset from the GOES satellite on 1 degree latitude-longitude grid spanning almost 2 yr (28 August 1998-30 June 2000). Poveda and Mesa [4] used the NCEP/NCAR Reanalysis to diagnose the annual cycle of the Chocó jet, whereas Zuluaga and Poveda [11] and Mejia and Poveda [16] used 1998-2002 information from the Tropical Rainfall Measuring Mission to diagnose the annual and diurnal cycle of rainfall and to quantify the atmospheric environments wherein MCSs develop over the region.

One of the main purposes of this study is to investigate the seasonal variability of moisture sources and the life cycle characteristics of western Colombian MCSs initiated both offshore and over land. For this purpose, a cloud cluster tracking scheme was applied in half hour infrared satellite images to identify and estimate main morphological features of convective systems. Moisture sources were identified based on a Lagrangian approach. These tools are tested in one year of data. Our approach differs from that of Mapes et al. [3, 14] who explored diurnal patterns based on precipitation data during two years (1998-2000) estimated from three hourly satellite images, as well as on ten days numerical model simulation to depict convection genesis characteristics. Beyond the temporal frequency of images, a difference that should be mentioned is the higher spatial resolution of satellite data used in this study compared to Mapes et al. $[3,14]$ work.

This paper is structured as follows. Section 2 describes the data and methods used in this study. Section 3 discusses the seasonal variability of MCS genesis and diurnal variations of their life cycles. Section 4 treats the diurnal life cycle and spatial dynamics of convective systems. The moisture sources related to systems genesis are presented in Section 5 . Finally, in Section 6, the main results are summarized and discussed.

\section{Data and Methods}

Infrared satellite images with $4 \mathrm{~km}$ horizontal resolution and thirty minutes intervals from CPC/NCEP/NWS (Climate Prediction Center/National Centers for Environmental Prediction/National Weather Service) were used to identify convective systems observed during the year 2003 [17].

Poveda and Mesa [4] observed that during El Niño events, the concomitant positive anomalies of sea surface temperatures over the Niño $1+2$ region are associated with a weakening of the Chocó low level jet, thus diminishing moisture advection from the Pacific to inland Colombia, which constitutes one of a suite of dynamical and thermodynamical mechanisms associated with negative anomalies in rainfall, river discharges, and soil moisture during El Niño in Colombia $[18,19]$. According to monitoring data from the Climate Prediction Center, the year 2003 started with a moderate El Niño condition during March-April-May and changed to a neutral condition in October-November-December. Therefore, we can conjecture that systems observed in 2003 were not particularly affected by El Niño. Although one year of data is not long enough to be considered climatologically meaningful, it may contribute to understand basic aspects of the seasonal and diurnal cycles of mesoscale convective systems over the region.

A cloud cluster tracking scheme called ForTraCC (Forecasting and Tracking the evolution of Cloud Clusters) 
was applied to IR satellite images to identify and track convective systems [20]. The system is detected assuming that high and thick convective clouds exhibit low brightness temperature. In agreement to other studies, such as Machado and Laurent [21] that analyzed Amazonian systems and Garreaud and Wallace [7] who used it to delimit convective cloudiness in their analysis over the Americas, we also adopt $235 \mathrm{~K}$ as temperature threshold to identify convective systems.

For our analysis, a convective system was defined as initiated when the system occupies at least 150 pixels (i. e., an area larger than $2,400 \mathrm{~km}^{2}$ ) in the satellite image. Following Machado and Laurent [21] methodology, only new systems were selected, which implies that those resulting from a split of a larger system or a merge of small ones were filtered out. These systems were tracked from the initiation phase (genesis), when a cluster matches the defined thresholds, through the mature phase, when the system achieves its largest horizontal extent, until the dissipation phase, when it reaches minimum cluster sizes and no longer complies with the temperature threshold condition. This procedure allows verifying their displacement throughout their life cycles. Details of the tracking methodology can be found in Vila et al. [20]. ForTraCC and similar satellite-based schemes have been used in several recent studies related to convection in South America (e.g., Machado and Laurent [21], Siqueira et al. [22], and Salio et al. [23]).

The study is focused on systems whose genesis was observed between the equator to $9^{\circ} \mathrm{N}$ and $76^{\circ} \mathrm{W}$ to $83^{\circ} \mathrm{W}$ along the Pacific coastline of Colombia. Only convective systems lasting more than 6 hours were considered. Those initially detected over the Pacific were classified as "oceanic;" otherwise they were categorized as "continental" systems. All selected systems were generalized as mesoscale convective systems (MCSs). Moisture sources associated with MCS genesis were identified based on the methodology developed by Stohl and James [24, 25], who used the Lagrangian particle dispersion model FLEXPART [25]. FLEXPART was driven by operational analyses from the European Centre for Medium-Range Weather Forecasts [26], with $1^{\circ} \times 1^{\circ}$ resolution, derived from T319 spectral truncation [27]. In FLEXPART, atmosphere is divided homogeneously into a large number of so-called particles. These particles are transported by the model using three-dimensional winds, with their positions and specific humidity $(q)$ being recorded every $6 \mathrm{~h}(00,06,12$, and $18 \mathrm{UTC})$, at all 60 vertical levels of analysis. Increases in moisture along the trajectory of each particle are due to evaporation $(e)$, whereas decreases are due to precipitation $(p)$, and can be estimated through changes in $q$ with time as $m(d q / d t)=e(t)-p(t)$, with $\mathrm{m}$ representing the mass of the particle.

As the interest is the identification of the origin of moisture sources that contribute to MCS genesis, we only select particles arriving with positive values of $d q / d t$ in an area of $4^{\circ} \times 4^{\circ}$ centered at each MCS initial position identified by ForTraCC. These moist particles were traced backward in time up to the previous 10 days, which is the average residence time of water in the atmosphere [28].

\section{Seasonal Variability}

During 2003, a total of 352 convective systems were detected in the area between the equator to $9^{\circ} \mathrm{N}$ and $76^{\circ} \mathrm{W}$ to $83^{\circ} \mathrm{W}$ (Figure 2). From this total, 191 systems were initially observed over the ocean. As the area monitored on the ocean is twice larger than on the continent, these numbers have to be analyzed in relative terms taking into account their sizes. Thus, considering the amount of systems per unit area, the number of continental systems was higher than the oceanic ones, representing $64 \%$ of all MCS. This is in agreement with typical observations of mesoscale convective systems in other areas $[11,29,30]$.

Concerning the seasonal variability, Figure 3 shows that continental and oceanic MCSs tend to be more frequent during the boreal summer and autumn (Table 1), in agreement with previous analysis $[9,11]$. System frequencies both at oceanic and continental regions grow from a minimum during the December-January-February (DJF) period to a maximum in September-October-November (SON). Maximum frequencies observed during the summer months are probably related to meridional migration of Intertropical Convergence Zone (ITCZ) [10]. The maximum in SON coincides with the maximum core wind velocities of the Chocó jet, which cause strong moisture advection from the Pacific Ocean to Colombia [4]. Horel et al. [6] also showed a trend of lower outgoing long wave radiation (OLR) from May to November in this area. In addition, Machado et al. [10] observed a peak of convective activity in the area from June to November.

It was also found that continental and oceanic systems observed during June-November exhibited longer life cycles compared to other seasons (see Figure 4 and Table 1). Although continental systems show longer life in winter compared to autumn events, as observed in ocean, those systems occurring during June-November reached maximum horizontal extent, possibly because of moisture availability. Furthermore, continental systems tend to exhibit, on average, longer life cycle than oceanic ones, in agreement with observations of Nesbitt and Zipser [31].

The systems observed over western Colombia last slightly longer than those observed by Velasco and Fritsch [9], who estimated an average lifetime of about 9 hours for the Americas low-latitude systems. Such difference could be explained in terms of the definition of life cycle duration. This depends on the space-time resolution of the satellite images, which is higher in the present study and thus enabled more detailed analysis. On the other hand, mean duration of the observed systems is in agreement with those studied by Machado et al. [10], around 12 to 18 hours in the tropical region of South America during boreal summer and autumn. With relation to the spatial extension of the systems, although our analysis showed systems with longer life cycles, the areal extensions are smaller than observed by Velasco and Fritsch [9]. This is because they concentrate their analysis on mesoscale convective complexes (MCCs), which are considered a particular class of weather systems, much more developed than ordinary MCS [32]. Therefore, 
TABLE 1: Summary of number, life cycle duration and maximum extension of the Ocean and Continent MCS during 2003 Boreal seasons.

\begin{tabular}{|c|c|c|c|c|c|c|}
\hline \multirow{2}{*}{ Boreal Season } & \multicolumn{2}{|c|}{ Number of MCS } & \multicolumn{2}{|c|}{ MCS life cycle duration (hours) } & \multicolumn{2}{|c|}{ MCS maximum extension $\left(10^{3} \mathrm{~km}^{2}\right)$} \\
\hline & Continent & Ocean & Continent & Ocean & Continent & Ocean \\
\hline Winter (DJF) & 36 & 31 & 12.1 & 9.4 & 42.0 & 26.4 \\
\hline Spring (MAM) & 26 & 40 & 10.7 & 8.9 & 40.8 & 29.6 \\
\hline Summer (JJA) & 49 & 51 & 14.5 & 11.4 & 86.3 & 52.6 \\
\hline Autumn (SON) & 50 & 69 & 11.6 & 11.2 & 52.3 & 47.4 \\
\hline Annual average* & 161 & 191 & 12.2 & 10.2 & 55.4 & 39.0 \\
\hline
\end{tabular}

${ }^{*}$ In case of number of MCS, the annual value corresponds to the total number of systems.

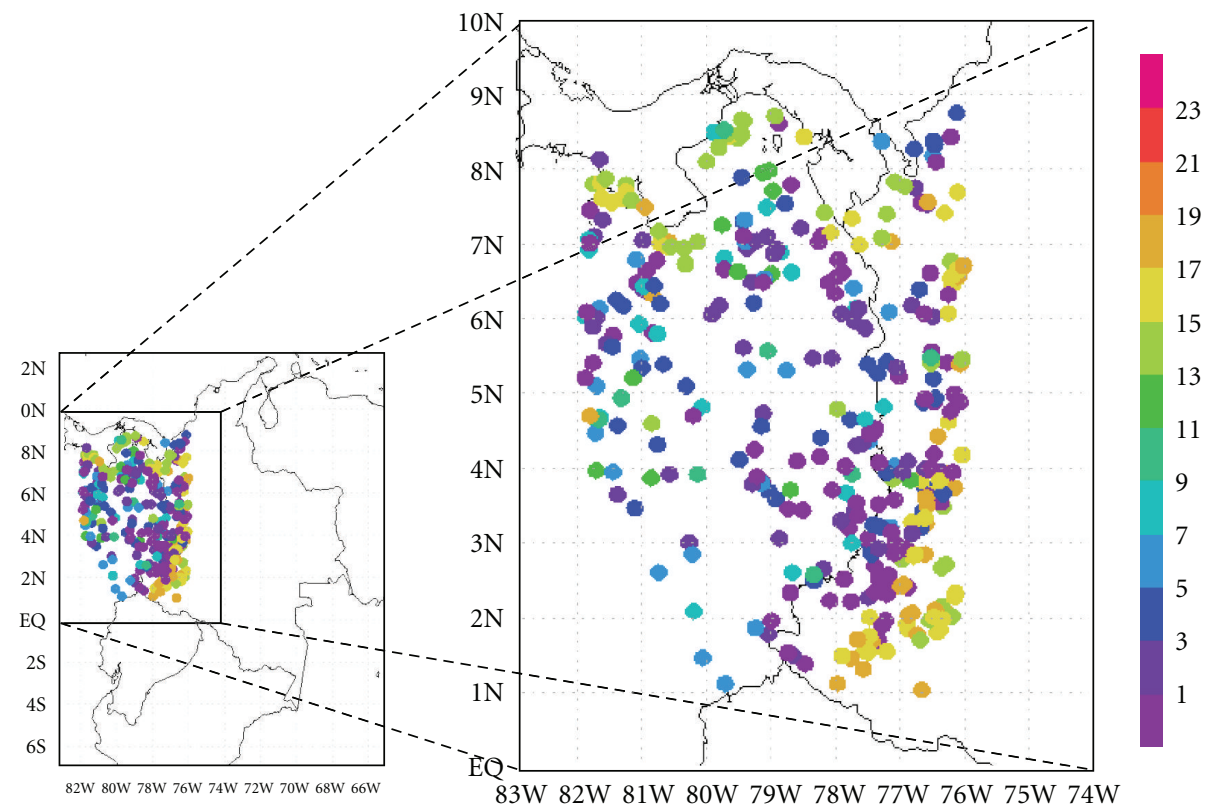

Figure 2: Mesoscale convective systems observed during 2003. Colored circles represent the position of the MCS at initial phase time (LST).

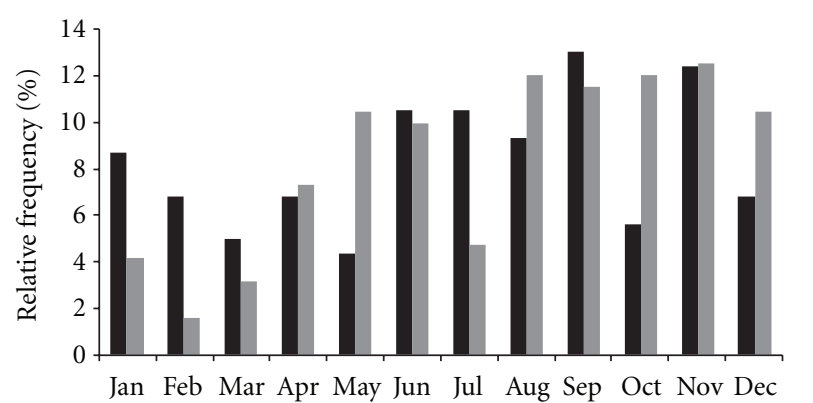

Months of 2003

- Continental MCS

- Oceanic MCS

FIGURE 3: Relative frequency of continental and oceanic convective systems observed during 2003.

the average spatial extension found by them is larger than the one in the present study.

\section{Diurnal Cycle and MCS Spatial Dynamics}

Regarding the average diurnal cycle (Figure 5(a)), continental systems tend to initiate mainly in the afternoon from 15 to 18 LST extending into nighttime, possibly related to the sea breeze and the diurnal heating cycle effects. A minimum genesis is observed during morning hours. The mature phase is pronounced during night through morning hours with a peak from 06 to 12 LST. The dissipation is observed throughout the day with a relative maximum from 12 to 15 LST. These results are in agreement with Velasco and Fritsch [9] observations for these latitudes, and also, with the diurnal cycle of rainfall rates, which occurs inland from 16 to 02 LST, as showed by Mapes et al. [3].

For oceanic systems (Figure 5(b)), the maximum of genesis is observed from 00 to 03 LST. Mature phase is observed slightly later, with a peak from 06 to 09 LST. The main dissipation period occurs around noon, with a peak from 12 to 15 LST. These results suggest a maximum of rainfall period from midnight to early morning, as showed by Mapes et al. [3]. The observed dynamic agrees with other studies over the tropical oceans [29, 33-36].

The difference between continental and oceanic systems diurnal cycle suggests that, to the later, the diurnal cycle of radiation alone cannot explain the systems life variations; regional physiographic characteristics or other dynamic and thermodynamic process affect MCS diurnal cycle. For instance, Gray and Jacobson [36] and Randall et al. [37] 


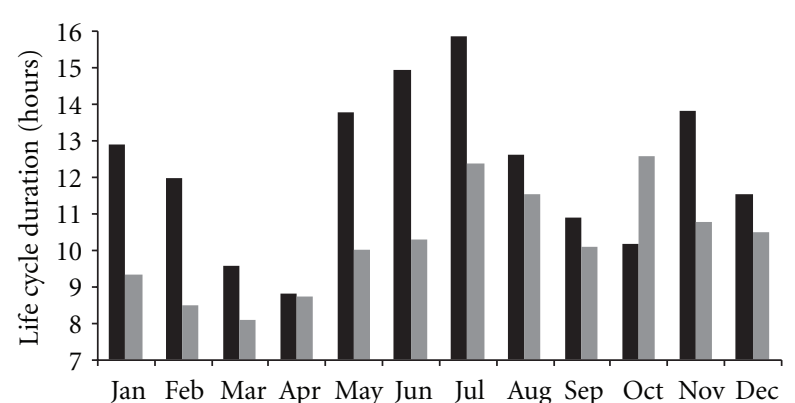

Months of 2003

(a)

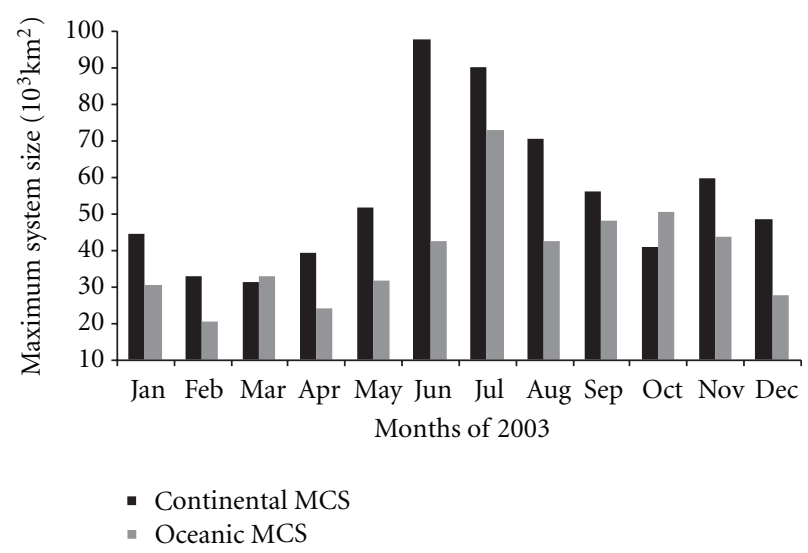

(b)

FIgURe 4: Continental and oceanic convective system characteristics: (a) Life cycle duration; (b) Maximum size area.

proposed interesting theories explaining the diurnal cycle variations observed in oceanic convective systems. According to Gray and Jacobson [36], the peak of convection during dawn and early morning periods results from the daily variation of the tropospheric radiative cooling between cloudy and the surrounding clear skies areas. Overnight, the atmospheric radiative cooling is greater in clear sky conditions than in cloudy areas, where the divergence at low levels would be lower. Randall et al. [37], in turn, suggest that the stabilization related to the absorption of solar radiation due to clouds would tend to suppress convection during the afternoon compared to the dawn period. Mapes et al. [14] suggested the existence of a diurnal gravity wave to explain those systems observed over the easternmost fringe of the tropical Pacific near Colombia. In accordance with these authors, as a result of the land heating and sea breeze, convective systems are generated during the evening over the Andes, thereby creating an east-west propagating gravity wave that produces early morning convection offshore.

The spatial dynamics of MCS was diagnosed between their positions at initial and dissipation stages. In agreement with Machado et al. [10], westward dominate over eastward trajectories throughout the year, as shown, for example, for the continental systems observed in June 2003 (Figure 6). However, MCS present intra-annual variability (Figure 7), with favored displacements to eastward in January (oceanic

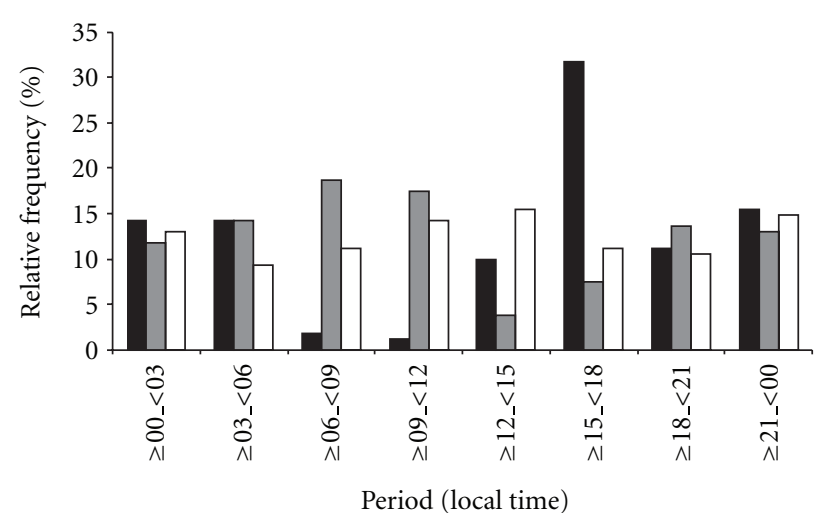

(a)

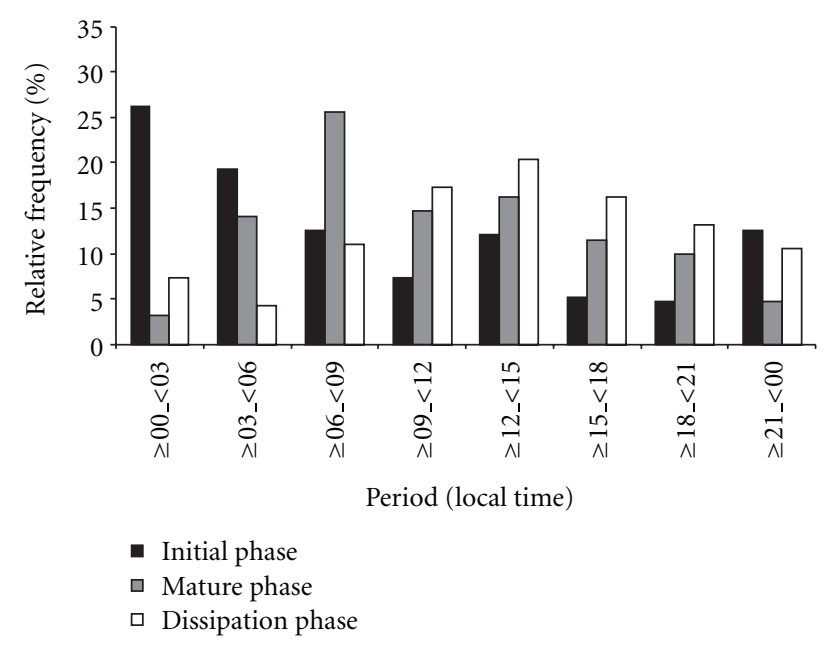

(b)

FIGURE 5: Average diurnal cycles of convective systems observed during 2003, over: (a) Continent; (b) Ocean.

systems) and February (oceanic and continental systems). A detailed analysis showed that in September, the predominant shift to the west presented a southwestward component almost in opposite direction to the Chocó low level jet, possibly reflecting the moisture source origin [38].

\section{Moisture Sources}

Unlike the traditional Eulerian perspective used by Poveda and Mesa [4], we use a Lagrangian approach to identify the sources of moisture contributing to MCSs dynamics. It is a somewhat new method which has been used for different purposes, such as (1) to detect humidity supply responsible for precipitation over river basins [24, 25], (2) to distinguish sources of moisture associated with water budget in different environments, such as the Sahel, Ireland, La Plata Basin, Central Brazil, and Norway [27, 39-41], and (3) to determine moisture sources associated with the initiation of convective systems in Europe [42, 43].

Figure 8 shows examples of typical trajectories of moisture parcels that contribute to continental and oceanic MCS genesis in western Colombia. The rectangles represent the area where MCSs are initiated. The reddish color means 


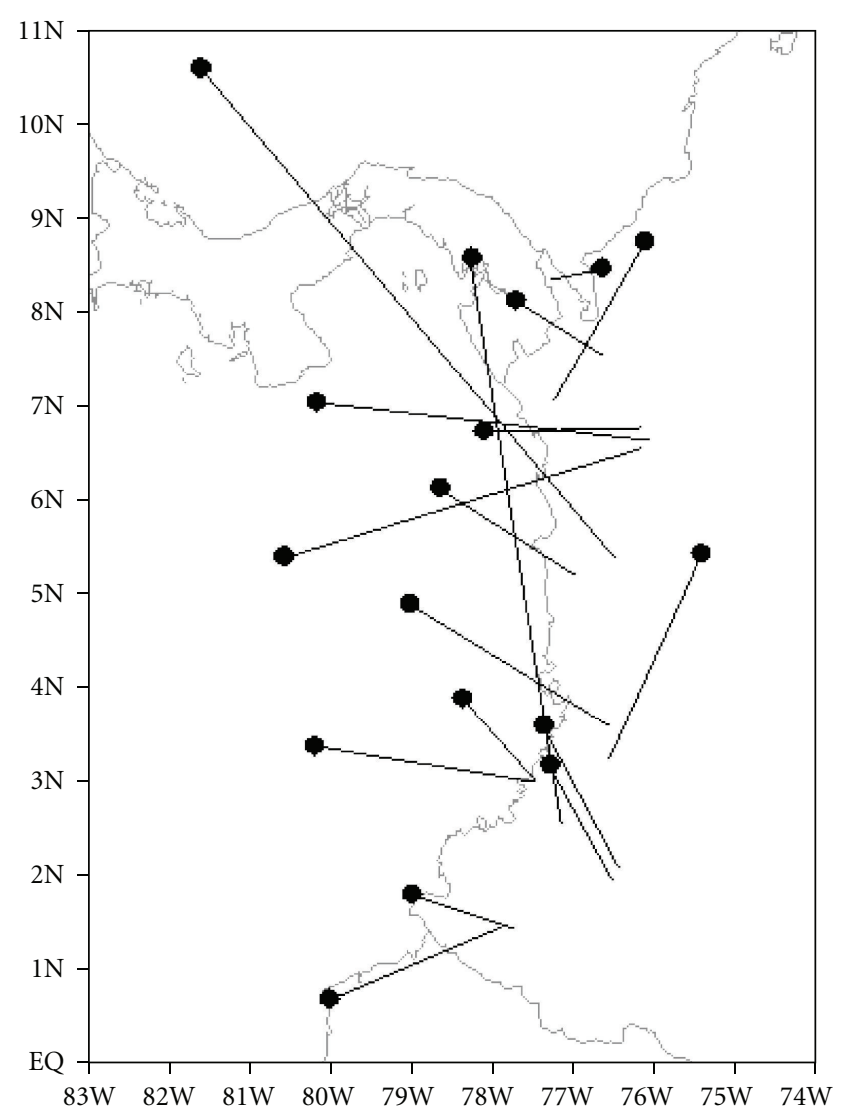

FIGURE 6: Continental convective systems displacements observed in July 2003. Black dot represents the position of the MCS at dissipation stage.

$e(t)-p(t)>0$ (where $t=6$ hours) represent humid air parcels. The bluish color means the opposite, $e(t)-p(t)<$ 0 which could be interpreted as a parcel losing moisture, or precipitating. Although the data allows the tracking of particles throughout all atmospheric column, in this figure we only show trajectories below 5,000 meters, which is the layer that holds more than $95 \%$ of water vapor in the atmosphere [44]. The figures also show trajectories up to ten days before the system genesis, which, according to Numaguti [28], is the average length of water vapor permanence in the atmosphere.

In the bottom of the figures, it is shown vertical profiles of the trajectories. Color variations depict the water balance at 6-hour resolution due to ECMWF analysis, during the ten-day tracking period. A particle arriving with moisture (reddish color) into the convective system genesis area could begin its propagation while precipitating (bluish color) and evaporating (reddish color) in the next period, and so on. Therefore, the parcel tracks help to identify their origin and trajectories through a dynamical picture of the water balance. In the examples, we choose two representative cases: a continental MCS, detected at 16:30 LST on September, 23, 2003, with 14 hours duration, showing typical moisture trajectories observed in autumn, with main moisture sources in Peruvian-Chilean Pacific and northern South America

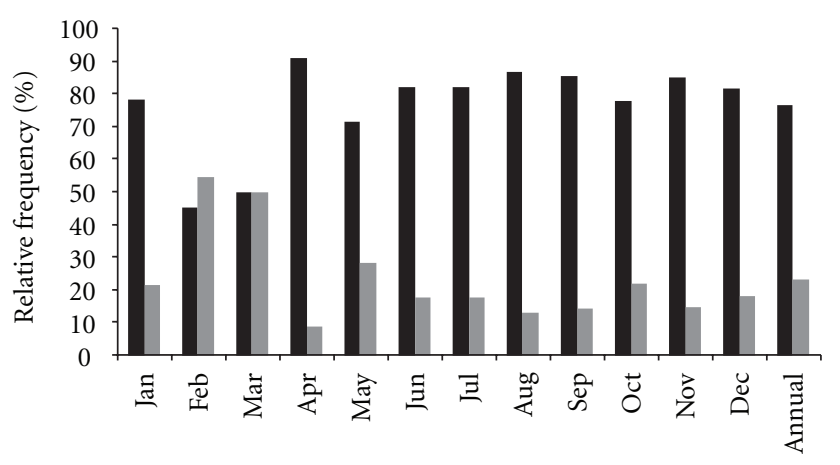

(a)

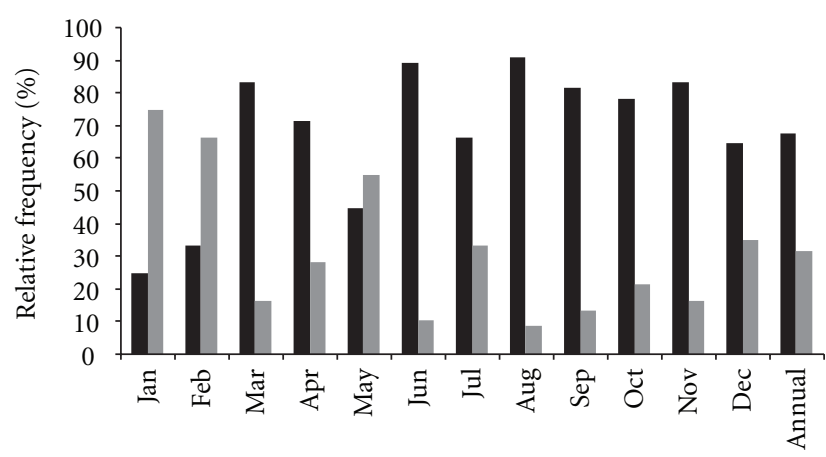

- Westward

- Eastward

(b)

FIGURE 7: Relative frequencies of convective systems according to their average displacement as observed during 2003 and the annual mean, for: (a) continental systems; (b) oceanic systems.

(Figure 8(a)); a characteristic winter pattern, with Caribbean Sea and tropical north Atlantic as moisture sources, observed in the genesis of a long lived oceanic MCS with a life cycle of 11 hours, identified at 07:30 LST, on January, 31, 2003 (Figure 8(b)).

The analysis of these trajectories associated to convective systems genesis in western Colombia indicated, in most cases, a combination of sources. These moisture contributions were summarized for each month, in Tables 2 and 3, respectively, to continental and oceanic systems. For example, in January, as showed in Table 2, 86\% of continental MCS presented Caribbean Sea and tropical north Atlantic as moisture sources to their genesis, and for others $14 \%$, tropical north Atlantic and Peruvian-Chilean Pacific were the sources of humidity that contributed to systems initiations.

During boreal winter, Caribbean Sea and tropical north Atlantic are the main sources for continental MCS generation (Table 2). These moisture trajectories configurations may result from the combined action between the moistureladen trade winds and the land-ocean temperature contrast over northern South America, which creates a favorable pressure gradient. Although it could be an unexpected flow pattern considering the presence of the Andes, in that region, the mountain is not as high as in other sectors of South America. There are passages where these parcels can pass over 


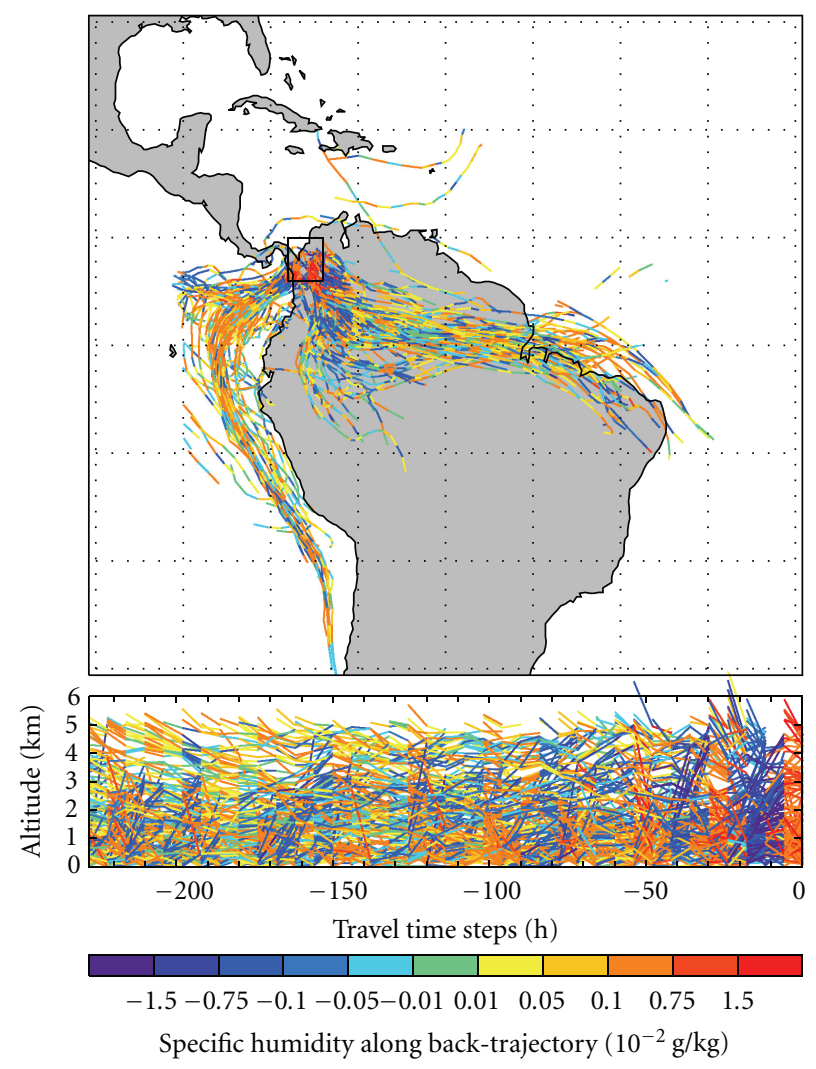

(a)

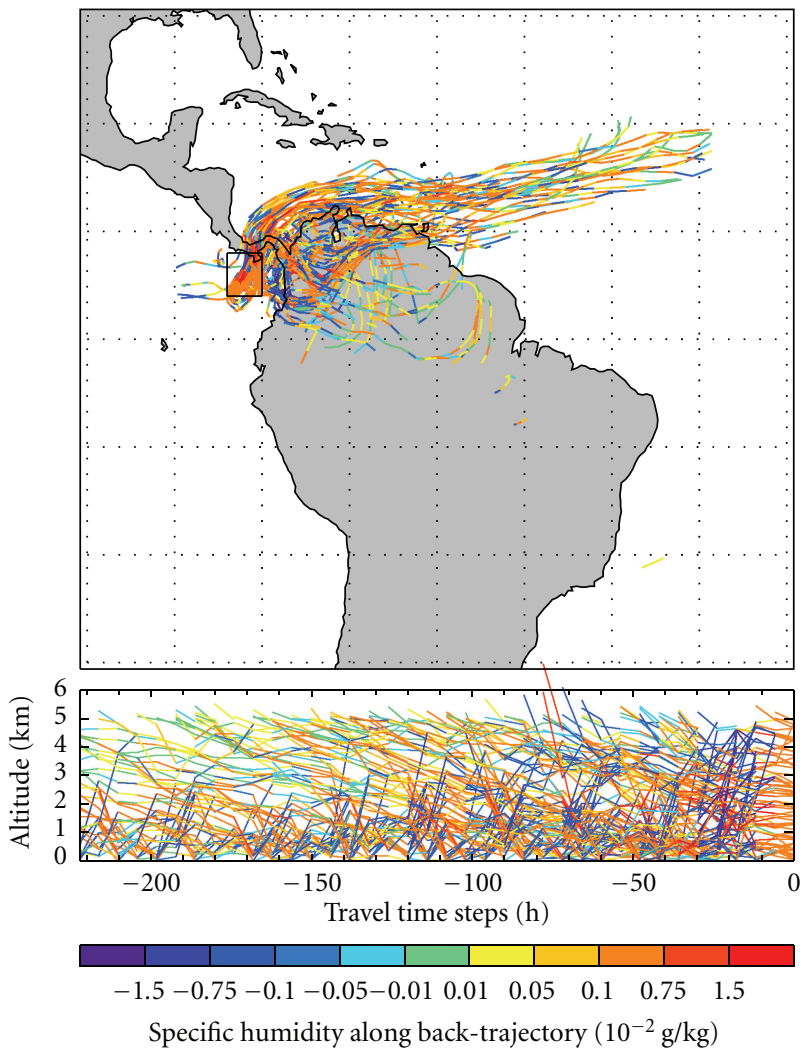

(b)

FIGURE 8: Examples of backward trajectories of moisture particles that contributed to MCS genesis observed: (a) over the continent in 2003/09/23; (b) over the ocean in 2003/01/31. Values of specific humidity are given in $10^{-2} \mathrm{~g} / \mathrm{kg}$.

the mountain range. On the other hand, the ECMWF model topography [26] shows, in this area, elevations averaging 3,000 meters which permit the passage of tracking flows below 5,000 meters. From May to September, continues the effect of tropical north Atlantic combined with other moisture sources, such as the tropical south Atlantic. PeruvianChilean Pacific is the key source of moisture to MCS genesis in the continental areas of western Colombia, predominantly from June to November, which confirms the effect of Chocó low level jet [4].

As showed in Table 3, for oceanic systems, the presence of Caribbean Sea as the main moisture source to MCS genesis is predominant from January to May, and the effect of tropical north Atlantic continues along the year until August. The other major moisture source to MCS initiation in the ocean is the Peruvian-Chilean Pacific which is predominant primarily from May to December. Comparatively to continental systems, the role of tropical south Atlantic is minimal, however, like in the continent, oceanic MCS genesis is less affected by other moisture sources such as central portions of South America.

\section{Discussion and Conclusion}

Moisture sources and life cycle of convective systems observed over western Colombia were analyzed. The main general conclusions, based on 2003 data, are that although most convective systems were generated over continental areas, in agreement to Velasco and Fritsch [9], both continental and oceanic MCS tend to be more frequent during boreal summer and autumn. During summer, the maximum frequencies are probably related to the meridional migration of ITCZ. On the other hand, the maximum MCS generation observed from September to November is possibly affected by moisture carried by Chocó low level jet which causes strong advection along the western coast of South America. Continental and oceanic MCS generated from June to November exhibited longer life cycle and reached maximum horizontal extent, probably because of moisture availability. Comparatively, in general, continental MCSs tend to present longer life than oceanic ones.

Concerning the diurnal cycle, the results indicated that continental MCS genesis is strongly affected by sea breeze and diurnal heating effects and presents a peak during afternoon and evening, from 15 to 18 LST. Mature phase tends to be pronounced during night through morning hours with a peak from 06 to 12 LST. Dissipation is observed along the day. Such behavior is observed mostly during May to July and is consistent with rainfall daily cycle in agreement with Velasco and Fritsch [9] results. In the case of oceanic systems, a peak of genesis is observed from 00 to 03 LST, with mature phase slightly later, and dissipation 
TABLE 2: Monthly moisture source origin and percentage of distribution considering continental convective system genesis.

\begin{tabular}{|c|c|c|c|c|c|c|c|c|}
\hline \multirow{2}{*}{ Month } & \multirow{2}{*}{$\begin{array}{l}\text { Moisture } \\
\text { source } \\
\text { distribution }\end{array}$} & \multicolumn{7}{|c|}{ Moisture source origin } \\
\hline & & $\begin{array}{l}\text { Caribbean } \\
\text { Sea }\end{array}$ & $\begin{array}{l}\text { Tropical } \\
\text { north } \\
\text { Atlantic }\end{array}$ & $\begin{array}{l}\text { Tropical } \\
\text { south } \\
\text { Atlantic }\end{array}$ & $\begin{array}{l}\text { Peruvian- } \\
\text { Chilean } \\
\text { Pacific }\end{array}$ & $\begin{array}{c}\text { Tropical } \\
\text { Pacific }\end{array}$ & $\begin{array}{l}\text { Northern } \\
\text { South } \\
\text { America }\end{array}$ & Central Brazil \\
\hline \multirow{2}{*}{ January } & $86 \%$ & & & & & & & \\
\hline & $14 \%$ & & & & & & & \\
\hline \multirow{2}{*}{ February } & $73 \%$ & & & & & & & \\
\hline & $27 \%$ & & & & & & & \\
\hline \multirow{3}{*}{ March } & $50 \%$ & & & & & & & \\
\hline & $25 \%$ & & & & & & & \\
\hline & $25 \%$ & & & & & & & \\
\hline \multirow{4}{*}{ April } & $37 \%$ & & & & & & & \\
\hline & $27 \%$ & & & & & & & \\
\hline & $18 \%$ & & & & & & & \\
\hline & $18 \%$ & & & & & & & \\
\hline \multirow{2}{*}{ May } & $86 \%$ & & & & & & & \\
\hline & $14 \%$ & & & & & & & \\
\hline June & $100 \%$ & & & & & & & \\
\hline July & $100 \%$ & & & & & & & \\
\hline \multirow{2}{*}{ August } & $67 \%$ & & & & & & & \\
\hline & $33 \%$ & & & & & & & \\
\hline \multirow{2}{*}{ September } & $81 \%$ & & & & & & & \\
\hline & $19 \%$ & & & & & & & \\
\hline \multirow{3}{*}{ October } & $45 \%$ & & & & & & & \\
\hline & $33 \%$ & & & & & & & \\
\hline & $22 \%$ & & & & & & & \\
\hline \multirow{4}{*}{ November } & $60 \%$ & & & & & & & \\
\hline & $25 \%$ & & & & & & & \\
\hline & $10 \%$ & & & & & & & \\
\hline & $5 \%$ & & & & & & & \\
\hline \multirow{4}{*}{ December } & $46 \%$ & & & & & & & \\
\hline & $27 \%$ & & & & & & & \\
\hline & $18 \%$ & & & & & & & \\
\hline & $9 \%$ & & & & & & & \\
\hline
\end{tabular}

in the late afternoon, which agree with maximum rainfall period from midnight to early morning. Thus, for oceanic MCS, the diurnal cycle of radiation cannot be the unique explanation for the systems' life activity; the dynamic and thermodynamic processes such as that discussed by Gray and Jacobson [36] and Randall et al. [37] may also have an important role in system development.

Generally, continental and oceanic MCS presented a tendency to westward trajectory, however, during boreal winter (mainly January and February), oceanic and continental systems showed eastward displacement. Another interesting aspect is the tendency to southwestward propagation of continental and oceanic MCS generated during September, in an opposite direction of the moisture source, which, at this period, is carried from the south Pacific by the Chocó low level jet. Further analysis is still necessary to better understand such opposite pattern behavior.

The Lagrangian approach used to identify moisture sources origins showed that to continental convective systems, during Boreal Winter, the main sources are Caribbean Sea and tropical north Atlantic, possibly as a result of the combined action between the moisture-laden trade winds and the land-ocean temperature contrast over northern South America. The first signs of the Peruvian-Chilean Pacific as main moisture source to MCS genesis appear in April. During Boreal Summer, mainly in June and July, the tracking shows the ITCZ positioning with moisture particles traveling from the tropical Atlantic over Amazonian river basin. In September and October, Peruvian-Chilean Pacific region prevails as the main moisture sources. In 
TABLE 3: Same as Table 2 but considering oceanic convective system genesis.

\begin{tabular}{|c|c|c|c|c|c|c|c|c|}
\hline \multirow{2}{*}{ Month } & \multirow{2}{*}{$\begin{array}{l}\text { Moisture } \\
\text { source } \\
\text { distribution }\end{array}$} & \multicolumn{7}{|c|}{ Moisture source origin } \\
\hline & & $\begin{array}{c}\text { Caribbean } \\
\text { Sea }\end{array}$ & $\begin{array}{l}\text { Tropical } \\
\text { north } \\
\text { Atlantic }\end{array}$ & $\begin{array}{l}\text { Tropical } \\
\text { south } \\
\text { Atlantic }\end{array}$ & $\begin{array}{l}\text { Peruvian- } \\
\text { Chilean } \\
\text { Pacific }\end{array}$ & $\begin{array}{c}\text { Tropical } \\
\text { Pacific }\end{array}$ & $\begin{array}{l}\text { Northern } \\
\text { South } \\
\text { America }\end{array}$ & Central Brazil \\
\hline \multirow{2}{*}{ January } & $63 \%$ & & & & & & & \\
\hline & $37 \%$ & & & & & & & \\
\hline \multirow{2}{*}{ February } & $67 \%$ & & & & & & & \\
\hline & $33 \%$ & & & & & & & \\
\hline \multirow{2}{*}{ March } & $50 \%$ & & & & & & & \\
\hline & $50 \%$ & & & & & & & \\
\hline \multirow{3}{*}{ April } & $50 \%$ & & & & & & & \\
\hline & $29 \%$ & & & & & & & \\
\hline & $21 \%$ & & & & & & & \\
\hline \multirow{4}{*}{ May } & $55 \%$ & & & & & & & \\
\hline & $20 \%$ & & & & & & & \\
\hline & $15 \%$ & & & & & & & \\
\hline & $10 \%$ & & & & & & & \\
\hline \multirow{3}{*}{ June } & $48 \%$ & & & & & & & \\
\hline & $26 \%$ & & & & & & & \\
\hline & $26 \%$ & & & & & & & \\
\hline \multirow{2}{*}{ July } & $67 \%$ & & & & & & & \\
\hline & $33 \%$ & & & & & & & \\
\hline \multirow{3}{*}{ August } & $61 \%$ & & & & & & & \\
\hline & $35 \%$ & & & & & & & \\
\hline & $4 \%$ & & & & & & & \\
\hline \multirow{2}{*}{ September } & $64 \%$ & & & & & & & \\
\hline & $36 \%$ & & & & & & & \\
\hline \multirow{3}{*}{ October } & $65 \%$ & & & & & & & \\
\hline & $30 \%$ & & & & & & & \\
\hline & $5 \%$ & & & & & & & \\
\hline \multirow{4}{*}{ November } & $70 \%$ & & & & & & & \\
\hline & $20 \%$ & & & & & & & \\
\hline & $5 \%$ & & & & & & & \\
\hline & $5 \%$ & & & & & & & \\
\hline \multirow{3}{*}{ December } & $55 \%$ & & & & & & & \\
\hline & $40 \%$ & & & & & & & \\
\hline & $5 \%$ & & & & & & & \\
\hline
\end{tabular}

November and December, the Pacific source is still observed, however, the main trajectory pattern shows contributions from tropical Atlantic area as moisture origin. Analogous intra-annual pattern variability is observed in oceanic MCS genesis, with a clear peak of Chocó low level jet contributing in moisture transport in September and October.

Although we have used just one year of data, a better picture of the MCS moisture source variability over the western Colombia was obtained using these new tools. Based on all the tracks available, a schematic seasonal pattern of the main moisture trajectories was summarized in Figure 9. Because the continental and oceanic MCS present a similar behavior concerning to moisture source origins, this figure represents the trajectories of both of them. While confirming the results from Poveda and Mesa [4] that indicated the importance of the Chocó low level jet in convective systems genesis, our results suggest that Pacific Peruvian-Chilean Pacific region works as an important moisture source during the Summer and Autumn. In winter and spring periods, Caribbean Sea and Tropical North Atlantic are the main source regions of the moisture in convection initiation in the area. These results also agree with other studies, like DuránQuesada et al. [45] who applied Lagrangian technique to identify moisture sources in Central America. 


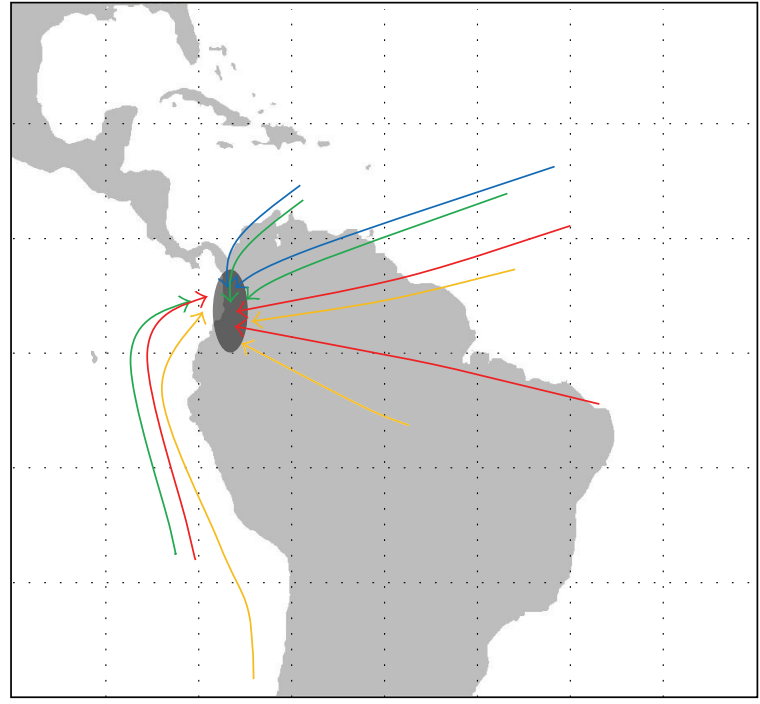

$\begin{array}{ll}\text { - Winter } & \text { - Summer } \\ \text { Spring } & \text { - Autumn }\end{array}$

FIGURE 9: Summary of the seasonal moisture particle trajectories which contribute to continental MCS genesis. Colors represent the trajectories for boreal: winter (blue), spring (green), summer (red) and autumn (orange).

A climatological study, that will permit to analyze some aspects, such as, the effect of ENSO in the moisture origin characteristics, is currently in progress and it will be presented elsewhere.

\section{Acknowledgments}

The authors thank anonymous reviewers for useful comments that helped improve the manuscript. They also would like to thank CNPq, CAPES, FAPESP and CLARIS LPB Project for their support.

\section{References}

[1] J. W. Snow, "The climate of northern South America," in Climates of Central and South America, W. Schwerdtfeger, Ed., pp. 295-403, Elsevier, Amsterdam, The Netherlands, 1976.

[2] J. A. Eslava, "Acerca de la distribución espacio-temporal de la precipitación en la región del Pacifico Colombiano," Atmosfera, vol. 22, pp. 71-80, 1994.

[3] B. E. Mapes, T. T. Warner, M. Xu, and A. J. Negri, "Diurnal patterns of rainfall in northwestern South America-part I: observations and context," Monthly Weather Review, vol. 131, no. 5, pp. 799-812, 2003.

[4] G. Poveda and O. J. Mesa, "On the existence of Lloró (the rainiest locality on earth): enhanced ocean-land-atmosphere interaction by a low-level jet," Geophysical Research Letters, vol. 27, no. 11, pp. 1675-1678, 2000.

[5] B. N. Meisner and P. A. Arkin, "Spatial and annual variations in the diurnal cycle of large-scale tropical convective cloudiness and precipitation," Monthly Weather Review, vol. 115, pp. 2009-2030, 1987.

[6] J. D. Horel, A. N. Hahmann, and J. E. Geisler, "An investigation of the annual cycle of convective activity over the tropical Americas," Journal of Climate, vol. 2, pp. 1388-1403, 1989.
[7] R. D. Garreaud and J. M. Wallace, "The diurnal march of convective cloudiness over the Americas," Monthly Weather Review, vol. 125, no. 12, pp. 3157-3171, 1997.

[8] R. F. Adler, G. J. Huffman, D. T. Bolvin, S. Curtis, and E. J. Nelkin, "Tropical rainfall distributions determined using TRMM combined with other satellite and rain gauge information," Journal of Applied Meteorology, vol. 39, no. 12, pp. 2007-2023, 2000.

[9] I. Velasco and J. M. Fritsch, "Mesoscale convective complexes in the Americas," Journal of Geophysical Research, vol. 92, no. 8, pp. 9591-9613, 1987.

[10] L. A. T. Machado, W. B. Rossow, R. L. Guedes, and A. W. Walker, "Life cycle variations of mesoscale convective systems over the Americas," Monthly Weather Review, vol. 126, no. 6, pp. 1630-1654, 1998.

[11] M. D. Zuluaga and G. Poveda, "Diagnostics of mesoscale convective systems over Colombia and the eastern Pacific during 1998-2002," Avances en Recursos Hidráulicos, vol. 11, pp. 145-160, 2004 (Spanish).

[12] G. Barnes, "Severe local storms in the tropics," in Severe Convective Storms, C. A. Doswell III, Ed., vol. 28 of Meteorological Monograph, pp. 359-432, American Meteor Society, 2001.

[13] C. A. Doswell, "Severe weather storms-an overview," in Severe Convective Storms, C. A. Doswell III, Ed., vol. 28 of Meteorological Monograph, pp. 1-26, American Meteor Society, 2001.

[14] B. E. Mapes, T. T. Warner, and M. Xu, "Diurnal patterns of rainfall in northwestern South America-part III: diurnal gravity waves and nocturnal convection offshore," Monthly Weather Review, vol. 131, no. 5, pp. 830-844, 2003.

[15] T. T. Warner, B. E. Mapes, and M. Xu, "Diurnal patterns of rainfall in northwestern South America-part II: model simulations," Monthly Weather Review, vol. 131, no. 5, pp. 813-829, 2003.

[16] J. F. Mejia and G. Poveda, "Atmospheric environments of mesoscale convective systems over Colombia during 1998 using TRMM and NCEP/NCAR reanalysis data," Revista Academia Colombiana de Ciencias, vol. 29, no. 113, pp. 495-514, 2005.

[17] J. E. Janowiak, R. J. Joyce, and Y. Yarosh, "A real-time global half-hourly pixel-resolution infrared dataset and its applications," Bulletin of the American Meteorological Society, vol. 82, no. 2, pp. 205-217, 2001.

[18] G. Poveda, A. Jaramillo, M. M. Gil, N. Quiceno, and R. I. Mantilla, "Seasonality in ENSO-related precipitation, river discharges, soil moisture, and vegetation index in Colombia," Water Resources Research, vol. 37, no. 8, pp. 2169-2178, 2001.

[19] G. Poveda, P. R. Waylen, and R. S. Pulwarty, "Annual and inter-annual variability of the present climate in northern South America and southern Mesoamerica," Palaeogeography, Palaeoclimatology, Palaeoecology, vol. 234, no. 1, pp. 3-27, 2006.

[20] D. A. Vila, L. A. T. Machado, H. Laurent, and I. Velasco, "Forecast and tracking the evolution of cloud clusters (ForTraCC) using satellite infrared imagery: methodology and validation," Weather and Forecasting, vol. 23, no. 2, pp. 233-245, 2008.

[21] L. A. T. Machado and H. Laurent, "The convective system area expansion over Amazonia and its relationships with convective system life duration and high-level wind divergence," Monthly Weather Review, vol. 132, no. 3, pp. 714-725, 2004.

[22] J. R. Siqueira, W. B. Rossow, L. A. T. Machado, and C. Pearl, "Structural characteristics of convective systems over South America related to cold-frontal incursions," Monthly Weather Review, vol. 133, no. 5, pp. 1045-1064, 2005. 
[23] P. Salio, M. Nicolini, and E. J. Zipser, "Mesoscale convective systems over southeastern South America and their relationship with the South American low-level jet," Monthly Weather Review, vol. 135, no. 4, pp. 1290-1309, 2007.

[24] A. Stohl and P. James, "A Lagrangian analysis of the atmospheric branch of the global water cycle-part 1: method description, validation, and demonstration for the August 2002 flooding in central Europe," Journal of Hydrometeorology, vol. 5, no. 4, pp. 656-678, 2004.

[25] A. Stohl and P. James, "A Lagrangian analysis of the atmospheric branch of the global water cycle-part II: moisture transports between earth's ocean basins and river catchments," Journal of Hydrometeorology, vol. 6, no. 6, pp. 961-984, 2005.

[26] ECMWF, IFS Documentation, Reading, UK, 2002, Edited by P. W. White.

[27] A. Drumond, R. Nieto, L. Gimeno, and T. Ambrizzi, "A Lagrangian identification of major sources of moisture over Central Brazil and la Plata Basin," Journal of Geophysical Research D, vol. 113, no. 14, Article ID D14128, 2008.

[28] A. Numaguti, "Origin and recycling processes of precipitating water over the Eurasian continent: experiments using an atmospheric general circulation model," Journal of Geophysical Research D, vol. 104, no. 2, pp. 1957-1972, 1999.

[29] A. G. Laing and J. M. Fritsch, "The global population of mesoscale convective complexes," Quarterly Journal of the Royal Meteorological Society, vol. 123, no. 538, pp. 389-405, 1997.

[30] J. D. Durkee and T. L. Mote, "A climatology of warm-season mesoscale convective complexes in subtropical South America," International Journal of Climatology, vol. 30, no. 3, pp. 418-431, 2010.

[31] S. W. Nesbitt and E. J. Zipser, "The diurnal cycle of rainfall and convective intensity according to three years of TRMM measurements," Journal of Climate, vol. 16, no. 10, pp. 14561475, 2003.

[32] R. A. Maddox, "Mesoscale convective complexes (USA)," Bulletin, American Meteorological Society, vol. 61, no. 11, pp. 1374-1387, 1980.

[33] J. E. Janowiak, P. A. Arkin, and M. Morrissey, "An examination of the diurnal cycle in oceanic tropical rainfall using satellite and in situ data," Monthly Weather Review, vol. 122, no. 10, pp. 2296-2311, 1994.

[34] B. E. Mapes and R. A. Houze Jr., "Cloud clusters and superclusters over the oceanic warm pool," Monthly Weather Review, vol. 121, no. 5, pp. 1398-1415, 1993.

[35] L. A. Toledo Machado, M. Desbois, and J. P. Duvel, "Structural characteristics of deep convective systems over tropical Africa and the Atlantic Ocean," Monthly Weather Review, vol. 120, no. 3, pp. 392-406, 1992.

[36] W. M. Gray and R. W. Jacobson Jr., "Diurnal variation of deep cumulus convection," Monthly Weather Review, vol. 105, pp. 1171-1188, 1977.

[37] D. A. Randall, Harshvardhan, and D. A. Dazlich, "Diurnal variability of the hydrologic cycle in a general circulation model," Journal of the Atmospheric Sciences, vol. 48, no. 1, pp. 40-62, 1991.

[38] J. M. Fritsch and G. S. Forbes, "Mesoscale convective systems," in Severe Convective Storms, C. A. Doswell III, Ed., vol. 28 of Meteorological Monograph, pp. 323-357, American Meteor Society, 2001.

[39] R. Nieto, L. Gimeno, D. Gallego, and R. Trigo, "Contributions to the moisture budget of airmasses over Iceland," Meteorologische Zeitschrift, vol. 16, no. 1, pp. 37-44, 2007.
[40] R. Nieto, L. Gimeno, and R. M. Trigo, "A Lagrangian identification of major sources of Sahel moisture," Geophysical Research Letters, vol. 33, no. 18, Article ID L18707, 2006.

[41] A. Stohl, C. Forster, and H. Sodemann, "Remote sources of water vapor forming precipitation on the Norwegian west coast at $60^{\circ} \mathrm{N}$ - a tale of hurricanes and an atmospheric river," Journal of Geophysical Research D, vol. 113, no. 5, Article ID D05102, 2008.

[42] P. James, A. Stohl, N. Spichtinger, S. Eckhardt, and C. Forster, "Climatological aspects of the extreme European rainfall of August 2002 and a trajectory method for estimating the associated evaporative source regions," Natural Hazards and Earth System Science, vol. 4, no. 5-6, pp. 733-746, 2004.

[43] R. García-Herrera, D. Barriopedro, E. Hernández, D. Paredes, J. F. Correos, and L. Prieto, "The 2001 mesoscale monvective systems over Iberia and the Balearic Islands," Meteorology and Atmospheric Physics, vol. 90, no. 3-4, pp. 225-243, 2005.

[44] D. J. Seidel, Water Vapor: Distribution and Trends, Encyclopedia of Global Environmental Change, John Wiley \& Sons, 2002.

[45] A. M. Durán-Quesada, L. Gimeno, J. A. Amador, and R. Nieto, "Moisture sources for Central America: identification of moisture sources using a Lagrangian analysis technique," Journal of Geophysical Research, vol. 115, article D05103, 15 pages, 2010. 

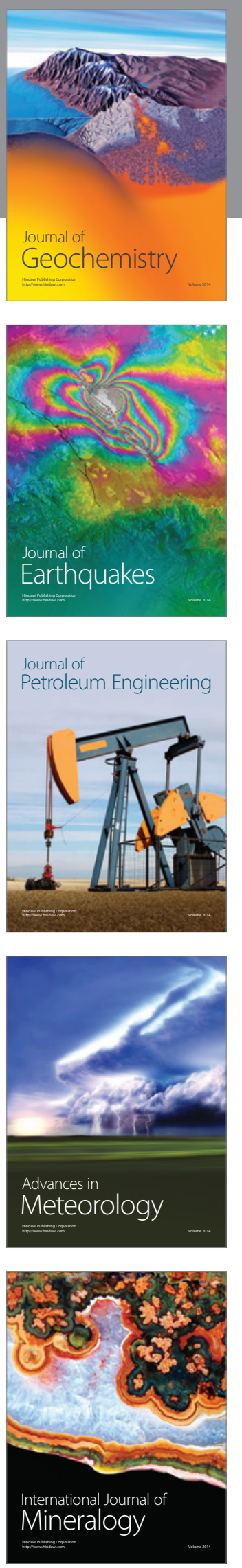
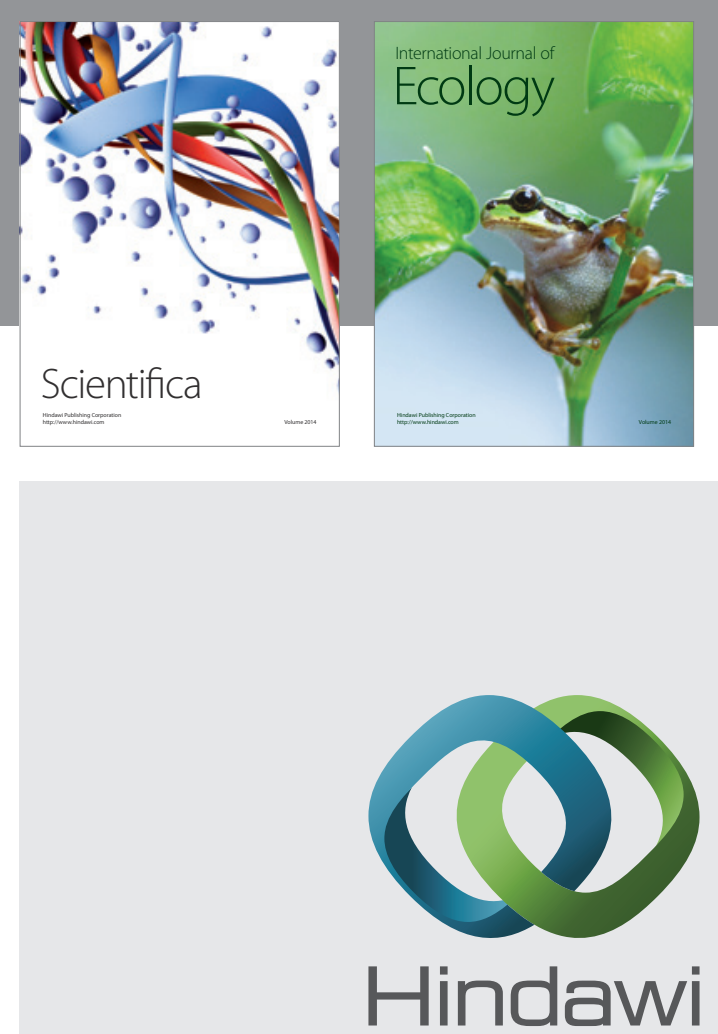

Submit your manuscripts at http://www.hindawi.com
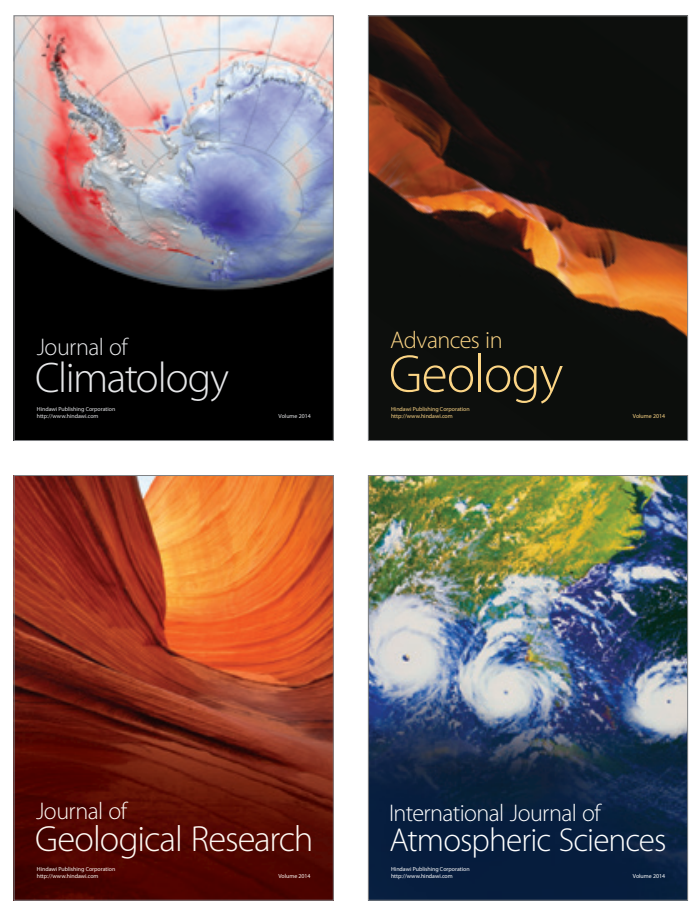
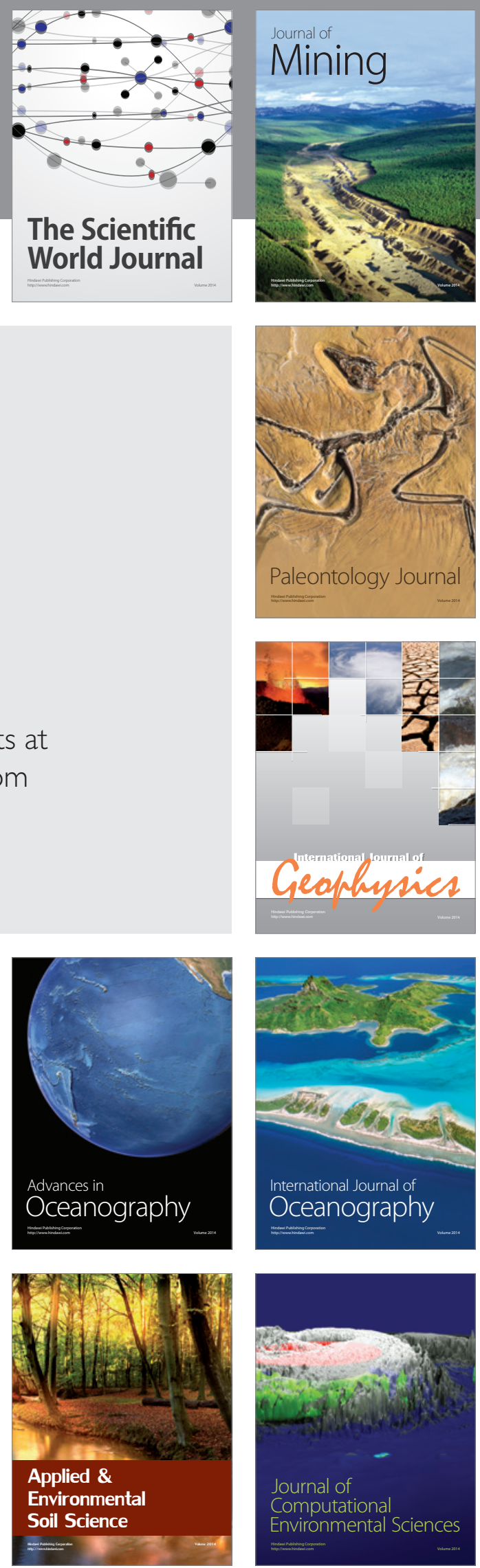